Dunamis: Jurnal Teologi dan Pendidikan Kristiani

Volume 4, Nomor 1 (Oktober 2019)

ISSN 2541-3937 (print), 2541-3945 (online)

http://www.sttintheos.ac.id/e-journal/index.php/dunamis

Submitted: 8 Juli 2019

Accepted: 3 Oktober 2019

Published: 28 Oktober 2019

\title{
Trauma Healing bagi Perempuan Korban Konflik: Belajar dari Konflik Maluku dan Poso
}

\author{
Asnath Niwa Natar \\ Fakultas Teologi Universitas Kristen Duta Wacana \\ asnathnatar@yahoo.com
}

\begin{abstract}
Conflicts that often occur in Indonesia claimed many victims. Among these victims, women were the largest impacted. They were not only being victims of violence and physicaly lost, but also experienced in psychological trauma. But this traumatic problem was hardly overcome by so it must be stayed and at the end would be choked the survival. This article aimed to discuss trauma healing efforts for women who are conflict impacted through literature study methods. Through this study it was concluded that giving opportunities for women conflict victims to tell their stories and experiences were the effective trauma healing efforts to heal the wounds they experienced.
\end{abstract}

Keywords: women; conflict victim; violence; trauma healing; feminism

\begin{abstract}
Abstrak
Konflik sering terjadi dalam kehidupan berbangsa dan bermasyarakat di Indonesia yang merengkut banyak korban. Di antara korban-korban tersebut perempuan mengalami dampak yang paling besar. Mereka bukan hanya menjadi korban kekerasan dan kerugian secara fisik, namun juga secara psikis, termasuk mengalami trauma. Namun masalah traumatis ini jarang mendapatkan penanganan sehingga menjadi menetap dan pada akhirnya menghambat pertumbuhan hidup selanjutnya. Artikel ini bertujuan untuk mengkaji upaya trauma healing bagi perempuan korban konflik melalui metode studi pustaka. Melalui kajian tersebut ditarik kesimpulan bahwa memberi kesempatan perempuan korban konflik untuk mengungkapkan kisah dan pengalamannya adalah upaya trauma healing yang efektif untuk menyembuhkan luka-luka yang mereka alami.
\end{abstract}

Kata Kunci: perempuan; korban konflik; kekerasan; trauma healing; feminisme 


\section{PENDAHULUAN}

Dunia di sekitar kita telah diliputi oleh berbagai macam kekerasan, dan perempuan lebih rentan terhadap kekerasan karena konstruksi sosial dan pra-paham yang menganggap perempuan sebagai manusia tingkat kedua dan lemah. Kekerasan terhadap perempuan lebih sering terjadi untuk mempertahankan norma-norma yang ada dalam budaya patriarkhi. Ideologi ini diperkuat oleh negara dan diperparah dengan penyalahgunaan agama.

Kekerasan yang diderita perempuan sepanjang hidupnya dimulai dari ketika janin perempuan masih di dalam perut ibunya. Janin itu mengalami aborsi karena jenis kelaminnya tidak dikehendaki. Ketika di dalam perut ibunya, ia sudah mengalami kekerasan fisik atau keberadaannya karena dipaksa melalui perkosaan (antara lain dalam peperangan).

Ketika lahir, bayi perempuan bisa dengan sengaja dibiarkan mati karena tidak dikehendaki kelaminnya, mengalami diskriminasi makanan dan kesehatan, mengalami kekerasan emosi dan fisik. Ketika masa kanak-kanak, perempuan mengalami kekerasan seksual bahkan incest, diskriminasi dalam akses terhadap makanan, pelayanan kesehatan, pendidikan dan prostitusi.
Ketika memasuki remaja, perempuan bisa mengalami kekerasan dari teman kencannya, kekerasan seksual karena alasan ekonomi, kekerasan seksual di tempat kerja, perkosaan, pelecehan seksual dan dipaksa menjadi pekerja seks. Saat memasuki usia dewasa, perempuan bisa mendapat kekerasan dari pasangan (suami). Hubungan seks yang dipaksakan oleh suaminya (marital rape) bahkan pembunuhan karena urusan mas kawin yang tidak memenuhi tuntutan keluarga laki-laki, kekerasan psikologis, kekerasan di tempat kerja, pelecehan seksual, pemerkosaan, kekerasan terhadap perempuan cacat. Kekerasan itupun masih dialami perempuan ketika ia sudah manula. Kekerasan terhadap manula umumnya dialami perempuan. Misalnya perlakuan kejam terhadap janda-janda dan perempuan tua, penghinaan, pengucilan, dipaksa untuk nurut, dan pencurian harta.

Akibat dari kekerasan terhadap perempuan digolongkan menjadi dua bagian yaitu: fisik dan emosional (psikis). Secara fisik, akibat kekerasan ada yang bersifat permanen, misalnya kehilangan pendengaran, kehilangan penglihatan, luka bakar yang membekas, cacat tubuh dan sebagainya. Dan tidak permanen misalnya memar, luka-luka sayatan, gegar otak, keguguran dan sebagainya. Dibandingkan dengan akibat fisik, akibat emosional 
dampaknya lebih parah karena mempengaruhi psikiloginya, misalnya rasa takut, cemas, stress post traumatik, ganguan pola makan dan tidur. Perempuan yang sering dianiaya bisa menjadi sangat tergantung, mudah dipengaruhi dan sulit mengambil keputusan sendiri. Apalagi kalau memiliki ikatan legal terhadap pelaku kekerasan maka akan meningkatkan perasaan kehilangan, penghianatan serta ketidakberdayaan, juga sering mengisolasi dan menarik diri karena ingin menyembunyikan keadaannya. Namun sayang, dalam kondisi seperti ini tidak atau kurang adanya pendampingan pastoral terhadap korban.

Hal yang sama juga terjadi pada perempuan yang menjadi korban akibat konflik yang terjadi di daerah mereka. Bantuan yang diberikan lebih pada bantuan yang menyangkut fisik seperti makanan, pakaian dan obat-obatan, sementara masalah psikis, dalam hal ini trauma yang dialami, jarang disentuh atau ditangani. Kaum perempuan sebagai korban terbanyak dalam sebuah konflik sering menjadi korban yang rentan untuk mengalami trauma akibat kehilangan anggota keluarga (suami, anak, saudara), mengalami penyiksaan dan pelecehan seksual. Peristiwa konflik itu sendiri bisa membekas dan berdampak panjang terhadap kesehatan mental kaum perempuan. Konflik dan dampaknya bisa menjadi memori buruk yang sulit terlupakan bila tidak disembuhkan.

Ada beberapa orang yang sudah membahas tentang perempuan di daerah konflik, seperti Margie Ivonne Ririhena-de Wanna, Merajut Identitas Eklesiologi di Seputar Konflik Lombok, Jakarta, BPK, 2015. Kajian ini menyangkut konflik di Lombok dan bagaimana keterlibatan kaum perempuan dalam upaya rekonsiliasi. Demikian pula dengan Rodolf Rahabeat, yang menyinggung sedikit tentang kekerasan yang dialami oleh perempuan korban konflik di Maluku dalam tulisannya yang berjudul "Potret Perempuan (berteologi) di ruang Konflik", dalam Perempuan, Konflik dan Rekonsiliasi, Perspektif Teologi dan Praksis, Basilica D. Putranti \& Asnath N. Natar (eds.), Yogyakarta, PSTF UKDW, 2004. Namun fokus kajiannya adalah bagaimana perempuan berteologi di ruang publik. Kajian yang lain adalah dari Lian Gogali, dengan judul kajian Konflik Poso. Suara Perempuan dan Anak Menuju Rekonsiliasi Ingatan, Yogyakarta, Galangpress, 2009. Namun sama dengan Margie dan Rodolf, kajian inipun lebih difokuskan pada keterlibatan kaum perempuan dalam upaya rekonsiliasi konflik. Dengan demikian, belum ada kajian yang secara khusus mengkaji tentang upaya trauma healing 
bagi perempuan korban di daerah konflik.

Sehubungan dengan hal ini, maka saya akan mengkaji upaya trauma healing terhadap perempuan korban di daerah konflik, secara khusus mereka yang mengalami trauma karena kekerasan akibat konflik berbasis politik, agama dan suku. Saya akan mengambil konflik Maluku dan Poso sebagai contoh kasus trauma healing bagi perempuan korban konflik. Tulisan ini diharapkan tidak hanya berguna untuk melakukan traumahealing bagi perempuan korban konflik di Maluku dan Poso, namun juga untuk korban-korban berikutnya yang mungkin terjadi, mengingat negara Indonesia sangat rawan akan berbagai macam konflik.

\section{METODE PENELITIAN}

Dalam penulisan ini digunakan metode penelitian studi pustaka, dengan memanfaatkan hasil penelitian dan bukubuku yang dihasilkan oleh penulis yang lain. Sedangkan metode penulisan yang digunakan adalah metode deskripsi analitis dimana konteks permasalahan diuraikan, kemudian dikaji dari perspektif feminis dengan menggunakan teori pendampingan pastoral.

Tahapan yang dilakukan adalah dengan terlebih dahulu mendeskripsikan konflik yang terjadi di Maluku dan di Poso yang terutama berdampak besar bagi kaum perempuan. Selanjutnya dikaji berbagai pandangan tentang kekerasan terhadap perempuan baik dari pandangan beberapa tokoh maupun kajian biblika terhadap 2 Samuel 13:1-39. Kajian terhadap teks 2 Samuel 13:1-39 akan dilakukan secara naratif. Setelah deskripsi dan analisis melalui kajian literatur maupun biblika tersebut, selanjutnya dilakukan upaya untuk menemukan metode trauma healing yang efektif bagi perempuan korban konflik.

\section{HASIL DAN PEMBAHASAN}

\section{Kekerasan Terhadap Perempuan} Akibat Konflik

Negara Indonesia merupakan negara yang sangat beragam. Keberagaman ini merupakan sebuah kekayaan, namun bisa juga menjadi sebuah sumber konflik bila tidak disikapi dengan baik. Dalam konflik-konflik yang terjadi, sering perempuan menjadi korban karena perempuan tidak bisa berlari cepat apabila ada serangan dari pihak lawan. Selain itu mereka juga harus melindungi anak-anak mereka. ${ }^{1}$ Kendati laki-laki dan perempuan sama-sama mengalami kekerasan atau menjadi korban dalam konflik, namun

\footnotetext{
${ }^{1}$ Lih. Eko Bambang Subiyantoro, "Perempuan Di Wilayah Konflik Maluku, Menakar Hidup Di Ladang Bedil," Jurnal Perempuan 24 (2002): 86; Lian Gogali, Konflik Poso. Suara Perempuan Dan Anak Menuju Rekonsiliasi Ingatan (Yogyakarta: Galangpress, 2009), 49.
} 
perempuan mengalami bentuk kekerasan yang lain lagi karena keperempuanan mereka, seperti perkosaan, pelecehan seksual, menjadi pelacur dan hamil paksa. ${ }^{2}$

\section{Konflik Maluku dan Poso}

Era reformasi di Indonesia bukan saja ditandai dengan pergantian rezim dan optimisme hadirnya sebuah tatanan baru yang damai dan adil, namun juga diwarnai dengan konflik berdarah dan pengorbanan. Rata-rata pemicu awal dari setiap konflik mirip, yaitu dimulai dengan pertengkaran kecil antara dua orang yang kemudian berkembang menjadi konflik besar yang melibatkan banyak orang disertai pelemparan dan pembakaran rumah-rumah penduduk dan rumah ibadah di sekitar tempat kejadian. Ini adalah peristiwa yang tidak wajar namun demikianlah yang terjadi hampir di setiap konflik. Seperti ada yang memberi komando atau telah

\footnotetext{
${ }^{2}$ Maggie Humm, seorang Feminis, mengatakan bahwa ada perbedaan antara laki-laki dan perempuan dalam mengalamai konflik, di mana laki-laki secara sosial diperbolehkan untuk menyalurkan agresinya, sebaliknya perempuan dibiasakan untuk memendam atau mengabaikan konflik dalam rangka mencapai feminitas. Perempuan yang menyalurkannya dalam bentuk agresi akan dipandang "sakit". Lih. Maggie Humm, The Dictionary of Feminist Theory, Second. (New York, US: Prentice Hall, 1989), 45. Namun di Ambon perempuan tidak saja menjadi korban, melainkan juga menjadi pelaku yang memanggul senjata dan membunuh pihak lawan. Lih. Rodolf Rahabeat, "Potret Perempuan (Berteologi) Di Ruang Konflik," in Perempuan, Konflik Dan Rekonsiliasi, Perspektif Teologi Dan Praksis, ed. Asnath Niwa Natar and Basilica D. Putranti (Yogyakarta: PSTF UKDW, 2004), 104.
}

merencanakan sebelumnya. Konflikkonflik kriminal murni ini selanjutnya dinaikkan eskalasinya menjadi isu konflik antar suku dan bermuara pada konflik agama.

Melihat pemicu awal dari setiap konflik yang terjadi, banyak orang menyimpulkan bahwa konflik-konflik yang ada bukan konflik agama namun agama digunakan untuk kepentingan tertentu. Lely Imoliana, seorang relawan kemanusiaan di Baileo Maluku, mengatakan bahwa konflik sosial yang melanda Maluku sangat sarat dengan peran dan keterlibatan unsur-unsur kepentingan elit politik lokal serta aparat militer di dalam setiap episode konflik. ${ }^{3}$ Ada juga yang melihatnya sebagai kurang atau memudarnya nilai-nilai traditional yang mengikat hubungan masyarakat, dan perebutan sumber daya atau ladang ekonomi. ${ }^{4}$ Namun kendatipun banyak dugaan yang dikemukakan, sampai saat ini orang tidak pernah tahu secara jelas apa yang telah terjadi dan apa penyebab yang sesungguhnya.

\footnotetext{
${ }^{3}$ Seperti dikutip oleh Julius Lawalata dalam tulisannya Julius Lawalata, "Fakta Tak Terlihat, Posisi Perempuan Dalam Konflik Sosial Di Maluku," Jurnal Perempuan 33 (2004): 15.

4 Teori Marxian mengatakan bahwa penolakan terhadap agama semata-mata merupakan ekspresi ketidakpuasan ekonomi dari kelas bawah, namun agama mampu mencegah kelas bawah untuk benarbenar mewujudkan kepentingan ekonomi mereka. Lih. M. McGuire, Religion: The Social Context (California: Wadsworth Inc., n.d.), 161.
} 


\section{Konflik di Maluku}

Konflik Maluku pada 19 Januari 1999 bermula dari sebuah peristiwa sepele yang terjadi di kota Ambon, yaitu pemalakan (minta uang) yang dilakukan oleh salah satu pemuda Islam dari keturunan Bugis (preman) kepada pemuda Kristen dari Mardika (sopir angkot). Preman ini sudah berkali-kali meminta uang, namun tidak diberikan oleh sopir angkot. Mereka kemudian beradu mulut dan saling pukul, yang berujung pada si sopir membawa parang untuk membunuh. ${ }^{5}$

Preman tersebut berhasil kabur ke arah daerah Islam dan mengatakan kepada warganya bahwa ia mau dibunuh oleh orang Kristen. Tanpa mencaritahu apa yang sesungguhnya terjadi, warga Islam marah dan menyerang desa Mardika dengan parang, tombak, dan senjata tajam lainnya. Mereka juga membakar ratusan rumah di desa Mardika termasuk Gereja Silale. Warga Kristen di sekitar Mardika marah, lalu menyerang balik warga Islam. Konflik ini juga merambat ke beberapa daerah di Maluku hingga pada akhirnya, kota Ambon menjadi porak poranda.

Konflik ini berlangsung selama tiga setengah tahun, yang terdiri dari 2 tahun

\footnotetext{
${ }^{5}$ Ellen Ferranda, "Sejarah Perang Ambon 1999 Secara Singkat Dan Lengkap," Sejarah Lengkap, December 17, 2018, accessed September 4, 2019, https://sejarahlengkap.com/indonesia/sejarahperang-ambon.
}

(1999-2001) konflik terbuka dan satu setengah tahun (2001-2002) konflik tertutup. ${ }^{6}$ Konflik ini mengakibatkan jumlah korban yang sangat besar dari kedua belah pihak (Islam dan Kristen) baik manusia maupun fasilitas. Ada banyak warga terluka dan meninggal, ratusan rumah hancur, fasilitas umum, hingga gereja setempat. Terjadi segregasi antara kelompok Kristen dengan kelompok Islam, baik itu tempat tinggal, pasar, sekolah dan perkantoran. $^{7}$

\section{Konflik di Poso}

Konflik Poso berawal dari bentrokan antara kelompok pemuda Islam dan pemuda Kristen yang terjadi pada tahun 1998 yang berlanjut pada konflik April 2000. Adapun masalahnya adalah persaingan ekonomi antara penduduk asli Poso yang mayoritas Kristen dengan para pendatang dari Bugis dan Jawa yang mayoritas Islam. Masalah lain adalah masalah kestabilan politik, persaingan antar pejabat pemerintah mengenai posisi birokrasi, dan pembagian kekuasaan daerah antara pihak Kristen dan Islam. ${ }^{8}$

\footnotetext{
${ }^{6}$ Weldemina Yudit Tiwery, Teologi Ina. Terlahir Dari Rahim Maluku (Jakarta: BPK Gunung Mulia, 2015), 3.

${ }^{7}$ Ferranda, "Sejarah Perang Ambon 1999 Secara Singkat Dan Lengkap."

8 "Kerusuhan Poso," Wikipedia bahasa Indonesia, ensiklopedia bebas, August 3, 2019, accessed September 4, 2019, https://id.wikipedia.org/w/index.php?title=Kerusuh an_Poso\&oldid=15423747.
} 
Pada bulan Mei 2000 konflik kembali terjadi dan lebih besar. Kalau pada konflik pertama, pihak Islam yang menyerang pihak Kristen, maka pada konflik ketiga ini, pihak Kristen menyerang balik pihak Islam. ${ }^{9}$ Konflik ini menyebabkan jatuh banyak korban pada kedua pihak. Tidak ada data yang jelas berapa banyak jumlah korban, namun menurut catatan versi pemerintah, terdapat 577 korban tewas, 384 terluka, 7.932 rumah hancur, serta 510 fasilitas umum terbakar atau rusak. Dalam sebuah penilaian kesehatan mental oleh pemerintah pada tahun 2001, mengindikasikan bahwa lebih dari 55 persen dari mereka yang mengungsi menderita masalah psikologis. ${ }^{10}$

\section{Kekerasan Terhadap Perempuan Sebagai Dampak Konflik}

Dampak konflik paling banyak dirasakan oleh kaum perempuan, baik pada saat terjadi konflik maupun pasca konflik. Dalam konflik, perempuan sering dijadikan bagian dari sasaran pelumpuhan yang sistematis atau menjadi target kekerasan (baik secara fisik, psikis maupun seksual). Perkosaan, penyiksaan dan pembunuhan terhadap perempuan dilakukan untuk memaksa suami mereka mengaku (sebagai alat kekerasan dan teror)

\footnotetext{
${ }^{9}$ Ibid.
}

atau untuk menghindari para perempuan melahirkan generasi berikutnya dari etnis tertentu (pembasmian etnis tertentu). Kaum perempuan juga menderita karena harus menyaksikan kematian anak dan suami di depan mata. Contoh kasus bisa dilihat pada konflik yang terjadi di Rwanda, Bosnia, kelakuan tentara Myanmar di bawah rezim militer, atau bahkan aktivitas militer Indonesia di beberapa daerah operasi militer di Aceh, Papua dan Timor-Timur. ${ }^{11}$ Perempuan Timor-Timur menjadi korban perkosaan dan janda korban perang. Selama 20 tahun mereka menerima dampak perang yang luar biasa buruknya. Beberapa di antara mereka menjadi gila, mengidap penyakit parah, dan mengalami trauma berkepanjangan. Secara ekonomi mereka juga sangat miskin, sulit untuk makan sehari-hari dan mengalami kekurangan gizi. $^{12}$

Hasil penelitian Jurnal Perempuan di beberapa daerah konflik menunjukkan bahwa selama konflik terjadi, perempuan mengalami teror, penggusuran, penyiksaan, pembunuhan, pelecehan

\footnotetext{
${ }^{10}$ Ibid.

${ }^{11}$ M. B. Wijaksana, "Reruntuhan Jiwa: Trauma Perempuan Poso," Jurnal Perempuan 24 (2002): 52.

${ }^{12}$ Pantoro Tri Kuswardono and Rosa M do R de Sousa, eds., Menyilam Kemarau. Upaya Perempuan Timor Loro Sae Menyudahi Kekerasan, Sebuah Awal (Dili: Forum Komunikasi Untuk Perempuan Loro Sae, 1999), 21.
} 
seksual, perkosaan dan lain sebagainya. ${ }^{13}$ Konflik yang terjadi di Poso dan Maluku telah menempatkan perempuan pada posisi sebagai korban yang mengalami penderitaan ganda. Perempuan harus menjadi saksi sekaligus korban dari kekejaman yang dilakukan terhadap suami, ayah, anak, saudara, tetangga dan dirinya sendiri. ${ }^{14}$ Konflik di Poso memperlihatkan bahwa ada banyak perempuan yang terpaksa menjadi janda akibat kehilangan suami dan menjadi penanggungjawab beban hidup keluarga. Bahkan ada sebuah desa yang disebut sebagai "desa janda" karena sebagian besar penduduknya adalah kaum perempuan yang kehilangan suaminya. Mereka harus mencari nafkah untuk keluarga dengan ancaman nyawa, ${ }^{15}$ (karena suami telah meninggal dalam konflik tersebut atau karena kaum perempuan mempunyai peluang lebih besar untuk bekerja dibandingkan kaum laki-laki). Misalnya di Maluku, perempuan Islam penjual ikan berani memasuki wilayah Kristen untuk menjajakan

\footnotetext{
${ }^{13}$ Nur Iman Subono, "Konflik Bersenjata, Kekerasan Militer Dan Perempuan," Jurnal Perempuan 24 (2002): 117-118.

${ }^{14}$ Dalam kondisi konflik, biasanya suami atau anak laki-laki dewasa yang dicari. Bila tidak ada mereka, maka perempuanlah yang disandera, diperkosa atau dibunuh. Lihat tulisan Subiyantoro, "Perempuan Di Wilayah Konflik Maluku, Menakar Hidup Di Ladang Bedil," 86.

${ }^{15}$ Gogali, Konflik Poso. Suara Perempuan Dan

Anak Menuju Rekonsiliasi Ingatan, 48.
}

ikannya, demi menghidupi keluarga. ${ }^{16}$ Dampak lain yang terjadi adalah sebagian perempuan terpaksa masuk ke dunia prostitusi. Ada juga perempuan yang menjadi korban kekerasan di dalam keluarga masing-masing karena banyak laki-laki mengalami stress atau frustrasi akibat konflik, dan istri atau anak menjadi sasaran atau pelampiasan kekerasan. ${ }^{17}$

Pelecehan seksual secara massal juga pernah terjadi di desa Sintuwulemba, saat terjadi konflik pada bulan Mei 2000 di Poso. Di sini perempuan dikumpulkan di satu tempat lalu ditelanjangi dengan tuduhan mereka menyembunyikan sesuatu yang berakibat buruk. ${ }^{18}$ Pasca konflik juga terjadi pelecehan dan kekerasan seksual yang dilakukan oleh sesama pengungsi laki-laki di tempat-tempat pengungsian. Hasil penelitian dari Jurnal Perempuan menunjukkan bahwa terdapat perempuan dan anak-anak perempuan (tidak disebutkan jumlahnya) yang menjadi korban incest. Ini terjadi karena kondisi di tempat pengungsian yang tidak memadai (laki-laki dan perempuan tidur bersamasama di satu tempat tanpa ada sekat dan

\footnotetext{
${ }^{16}$ Rachel Iwamony-Tiwery, "Keterlibatan Dan Peran Perempuan Dalam Dialog Antar Umat Beragama Paska Konflik Di Ambon. Tinjauan Teologi Interkultural," in Ketika Perempuan Berteologi, ed. Asnath Niwa Natar (Yogyakarta: Taman Pustaka Kristen, 2012), 80-81.

${ }^{17}$ Subiyantoro, "Perempuan Di Wilayah Konflik Maluku, Menakar Hidup Di Ladang Bedil,” 88-89.

${ }^{18}$ Gogali, Konflik Poso. Suara Perempuan Dan Anak Mепијu Rekonsiliasi Ingatan, 48-49.
} 
kamar mandi seadanya sehingga mudah diintip ketika sedang mandi).

Tidak hanya itu, perempuan juga mengalami pelecehan seksual yang dilakukan oleh aparat keamanan yang sedang bertugas menjaga keamanan di daerah itu. KPKP-ST (Ornop perempuan di Sulawesi Tengah) melaporkan bahwa sejak operasi Sintuwu Maroso, terdapat kurang lebih tiga sampai enam perempuan di setiap desa di 14 kecamatan dari kabupaten Poso yang mengalami kehamilan yang tidak diinginkan dan pemerkosaan yang dilakukan oleh aparat keamanan. ${ }^{19}$ Kisah yang sama juga terjadi pada gadis-gadis di Maluku pasca konflik di mana para aparat yang bertugas di tempat itu untuk beberapa bulan, berpacaran dengan gadis-gadis setempat dan menghamili mereka, setelah itu ditinggal tanpa pertanggungjawaban. Para gadis ini dilabeli dengan istilah KORAMIL (Korban Rayuan Militer) atau BCA (Bajalang/Berjalan Cari Aparat). ${ }^{20}$ Mereka adalah korban namun justru disalahkan, sementara pelakunya, tidak mendapatkan tindakan apapun.

$$
\text { Budaya patriarkhi telah }
$$
menempatkan laki-laki pada posisi yang memiliki kuasa termasuk berkuasa atas tubuh perempuan, sementara perempuan

\footnotetext{
${ }^{19}$ Ibid., 50-52.

${ }^{20}$ Rahabeat, "Potret Perempuan (Berteologi) Di
}

berada pada posisi lemah dan tidak berdaya untuk melawan. Kondisi ini membuat kehidupan kaum perempuan di daerah konflik semakin terpuruk karena mereka tidak hanya menanggung beban penderitaan akibat kehilangan harta benda, suami dan anak laki-laki yang selama ini menjadi tulang punggung keluarga, namun ditambah lagi dengan pelecehan seksual yang terjadi terhadap janda dan anak gadis. Semua masalah ini membekas dalam ingatan kaum perempuan dan menjadi pengalaman traumatis bagi mereka, walau tingkat trauma tidak sama pada semua perempuan. Perempuan menjadi kelompok masyarakat yang paling rentan terhadap penyakit kejiwaan yang bisa berupa histeria, depresi, trauma dan gangguan kejiwaan lainnya akibat kerusuhan dan konflik. $^{21}$

Kendati demikian, tekanan-tekanan yang telah menimbulkan trauma dan luka batin yang berkepanjangan pada kaum perempuan ini jarang sekali mendapat perhatian baik dari pemerintah maupun media massa. Hal ini dikatakan oleh M.B. Wijaksana, seorang peneliti di daerah konflik. Pemerintah lebih memusatkan

Ruang Konflik," 106.

${ }^{21}$ Mereka mengalami ketakutan bila mendengar suara tiang listrik yang dipukul (dibunyikan sebagai tanda bahaya bila ada serangan dari pihak musuh), bunyi Truk (biasanya digunakan untuk mengangkut pasukan dan tawanan), atau bila melihat simbolsimbol agama seperti pakaian pendeta atau jilbab dan sorban yang dipakai oleh orang Islam. 
perhatian pada perbaikan sarana prasarana dan ekonomi, sedangkan upaya pemulihan mental perempuan yang traumatik diabaikan. Masalah perempuan tidak dipandang sebagai persoalan, sehingga tidak menjadi prioritas. Mereka malah mengusulkan agar para pemuka agama memberikan pengarahan dari sudut agama pada para korban dan menentramkan kejiwaan melalui sentuhan rohani. Misalnya dengan meminta tenaga rohaniawan baik dari kalangan Islam maupun kalangan Kristen untuk memimpin ibadah di tempat pengungsian dan berdoa bagi mereka. ${ }^{22}$ Aspek agama memang dapat menolong para korban, namun dalam kasus ini agak kurang tepat dan tidak bisa menolong para korban, apalagi konflik yang terjadi adalah konflik berbasis agama, di mana mereka tentunya sedang mempertanyakan fungsi dan makna agama itu sendiri. Para korban butuh ruang dan tempat yang aman untuk mengutarakan apa yang mereka pikirkan dan rasakan. Mereka butuh didengarkan. Gay Hubbard menyarankan agar pendamping dapat memperlihatkan perhatiannya pada perempuan itu sendiri sebagai korban, dan pada apa yang

${ }^{22}$ Lihat Tulisan Wijaksana, "Reruntuhan Jiwa: Trauma Perempuan Poso," 58-59. Pemerintah merasa tidak atau kurang memiliki sumber daya namun tidak memanfaatkan LSM-LSM yang ada. dibutuhkan. ${ }^{23}$

Perempuan Korban Kekerasan Dalam 2 Samuel 13:1-39

Kekerasan terhadap perempuan tidak hanya menimpa kaum perempuan saat ini, namun sudah terjadi ribuan tahun yang lalu, termasuk dalam konteks Alkitab. Dalam peperangan antara bangsa Israel dengan bangsa lain, kaum perempuan tidak ikut berperang, tetapi mereka justru menjadi tawanan perang yang akan dibagi-bagikan oleh mereka yang menang (lihat 1 Sam. 30:1-10, Hak.5:30) selain itu, mereka juga kehilangan suami, ayah dan anak laki-laki mereka (baca 1 Sam, 15: 3 dan 33, 22:19, dan 27:9). ${ }^{24}$ Kendati perempuan menjadi korban, namun mereka menjadi pihak yang pasif, bungkam dan terabaikan. Suara dan penderitaan mereka tidak didengar dan diberi tempat.

Kepasifan dan kebungkaman juga terjadi pada kisah perkosaan yang dialami oleh Tamar dalam 2 Samuel 13:1-39. Kisah kekerasan ini memang bukan dalam konteks konflik antara dua kelompok besar, namun yang mau disoroti dalam

${ }^{23}$ M. Gay Hubbard, Women: The Misunderstood Majority (USA: Word Publishing, 1992), 234.

${ }^{24}$ Lihat Ilse Muellner, "Die Samuelbuecher. Frauan Im Zentrum Der Geschichte Israels," in Kompendium Feministishe Bibelauslegung, ed. Luise Schottroff and Marie-Theres Wacker (Guetersloh: Guetersloher Verlaghaus, 2007), 117. 
kisah ini adalah pembungkaman terhadap Tamar (perempuan) sebagai korban dan tidak adanya penanganan pastoral atau trauma healing terhadap korban. Pelaku dalam kisah perkosaan terhadap Tamar adalah Yonadap (sepupu Tamar) dan Amnon (kakak Tamar, dari ayah yang sama (Daud) tetapi beda ibu). Mereka merencanakan perbuatan yang jahat terhadap adik perempuan mereka, yang seharusnya dilindungi. Justru kakakkakaknya ini yang melakukan tindakan keji pada diri Tamar. Namun Tamar tidak menaruh curiga sama sekali ketika ayahnya meminta dia menjenguk, membuat kue buat kakaknya (Amnon) bahkan ketika ia disuruh oleh Amnon untuk masuk ke kamar, karena ia yakin sekali kakaknya tidak akan melakukan hal yang jahat pada dirinya. Apalagi dalam tradisi Israel saat itu bahwa tidaklah berlaku hal seperti itu di Israel karena akan dianggap sebagai orang bebal (ayat 12-13).

Ketika ia diajak tidur oleh Amnon, ia menolak, bahkan menasihati Amnon dengan bijaksana bahwa apabila Amnon memang berniat terhadapnya, supaya ia meminta saja pada ayah mereka Daud (ayat 12-13 \& 16). Tetapi Amnon tidak mendengarkan, dan terjadilah perkosaan itu. Di sini nampak bahwa ketika perempuan itu berbicara, suaranya tidak didengarkan. Hal yang menarik untuk diperhatikan adalah sikap Amnon kepada Tamar. Sebelum perkosaan atau niatnya tercapai, Amnon menyebut Tamar "adik", tetapi sesudah perkosaan, ia menyebut Tamar dengan kata "perempuan." Sebutan "adik" adalah sebutan yang ramah dan penghargaan sebagai saudara. Namun berbeda dengan sebutan "perempuan," sebuah sebutan yang tidak menunjuk sapaan persaudaraan yang ramah, melainkan suatu sebutan yang sangat kasar dan merendahkan Tamar. Sebutan perempuan biasanya digunakan ketika seseorang ingin merendahkan perempuan tersebut sekaligus menunjukkan posisinya yang tidak setara dengan laki-laki. ${ }^{25}$ Pada awalnya (sebelum memperkosa) ia jatuh hati pada Tamar, namun setelah niatnya itu sudah terlaksana, ia kemudian membenci, malah dikatakan lebih dari sebelumnya, dan mengusir Tamar (korban) dengan kasar. Sekali lagi Tamar memprotes bahwa tindakan Amnon mengusirnya adalah tindakan yang jahat, namun suara Tamar tidak didengarkan dan tidak dipedulikan.

Hal yang sama juga terjadi ketika Tamar bertemu dengan kakak kandungnya

\footnotetext{
${ }^{25}$ Pada masa yang lalu, jarang kita mendengar seorang laki-laki memaki dengan menyebut wanita tetapi menggunakan perempuan. Namun sebenarnya dari segi arti sebutan perempuan justru lebih bagus karena berasalah dari akar kata етри: tuan. Sedangkan kata wanita berarti wani ditata (berani diatur). Itulah sebabnyauntuk saat ini, kaum perempuan lebih suka menyebut perempuan daripada wanita.
} 
Absalom. Ketika Tamar pulang dengan mengenakan abu dan mengoyak jubahnya, Absalom memang menanyakan apa yang terjadi. Namun jawaban Absalom sangat mengecewakan. Ia bukannya bertindak malah sebaliknya ia meminta Tamar diam (membungkam) dan tidak memikirkan perkara itu dengan alasan bahwa Amnon adalah kakaknya sendiri. Ini merupakan tindakan kekerasan ketiga yang dialami oleh Tamar, setelah kekerasan seksual (perkosaan) dan pengusiran yang ia alami. Tamar tidak diberi kesempatan untuk menjawab pertanyaan ataupun menyelesaikan masalahnya sendiri. Ia kemudian tinggal di rumah Absalom seorang diri. Bagi Tamar, rumah Absalom bukanlah tempat yang aman, melainkan tempat pembungkaman (kebisuan). ${ }^{26}$

Sikap ayahnya Daud juga tidak berbeda dengan Absalom. Ketika Daud mendengar apa yang terjadi pada Tamar, ia memang marah (tidak jelas marah pada siapa) tetapi ia tidak berbuat apa-apa untuk Tamar. Daud tidak menghukum Amnon atas perbuatannya itu, kemungkinan karena Amnon adalah putra mahkota. ${ }^{27}$ Sebaliknya ia menangisi kematian Amnon (pelaku perkosaan) tetapi ia tidak pernah

\footnotetext{
${ }^{26}$ Muellner, "Die Samuelbuecher. Frauan Im Zentrum Der Geschichte Israels," 122.

${ }^{27}$ Jo Ann Hackett, "1 and 2 Samuel," in Women'n Bible Commentary, ed. Carol A. Newsom and Jaqueline E. Lapsley, Revised and Updated (Louisville, Kentucky: Westminster John Knox
}

menangis untuk apa yang telah terjadi pada Tamar (korban). Seolah-olah anak perempuan tidak ada harganya. Dalam budaya Israel yang menganut budaya patriarkhi, perempuan memang menempati posisi nomor dua setelah laki-laki. Lakilaki, termasuk anak laki-laki lebih penting dari perempuan dan anak perempuan, dan perempuan adalah milik laki-laki yang setara dengan hewan peliharaan mereka. Perempuan berada di bawah kendali lakilaki. Jadi kendati perempuan di sini adalah korban namun hal ini tidak dipandang sebagai hal yang penting untuk diurus. Daud lebih memperhatikan nasib si pemerkosa dan menangisinya tetapi tidak untuk korban pemerkosaan. Daud juga merindukan Absalom (tidak marah lagi pada Absalom), memberi perhatian pada Absalom tetapi tidak pernah merindukan dan memberi perhatian pada Tamar. Tamar dan kisahnya menjadi terlupakan.

Pada ayat 23 dikatakan bahwa setelah 2 tahun lebih, Absalom membunuh Amnon. Ada kesan bahwa pembunuhan ini bukan dalam rangka membela Tamar tapi lebih untuk membela harga dirinya sebagai seorang laki-laki (kakak Tamar), karena ternyata Absalom tidak berbuat apa-apa untuk Tamar. Ada kemungkinan Absalom membunuh Amnon juga karena masalah perebutan kekuasaan, dan kisah Tamar

Press, 2016), 161. 
hanya disisipkan saja. Lamanya waktu (2 tahun) Amnon dibunuh, menunjukkan betapa lamanya masalah itu dibiarkan begitu saja (tidak diselesaikan). Ketika Amnon sudah dibunuh pun persoalan Tamar sebenarnya belum selesai. Ia tidak dilibatkan dalam upaya penyelesaian masalahnya. Kisahnya berhenti begitu saja dan berubah menjadi persoalan antara lakilaki dengan laki-laki, bukan perempuan dengan laki-laki. Suara Tamar dibungkam dan tidak pernah ada traumahealing atau penyembuhan atas trauma akibat perkosaan yang dia alami.

\section{Trauma Healing Bagi Perempuan}

\section{Korban Konflik}

Konflik telah menghasilkan trauma, dan trauma tercetak dalam bentuk struktur atau pola sosial masyarakat, yang bisa jadi akan terulang lagi di masa yang akan datang. ${ }^{28}$ Renate Jost ${ }^{29}$ memberikan pengertian trauma sebagai luka jiwa dan fisik yang jika tidak diolah dan diatasi dapat menuntun pada sebuah fiksasi yang dapat menganggu hidup manusia sebagian atau seluruhnya. Sementara Judith Herman

\footnotetext{
${ }^{28}$ Ketika trauma timbul, lepas dari apakah sebab utama masih ada atau tidak, efek dari trauma tersebut akan terus ada untuk waktu yang sangat lama. Selama korban dan pelaku masih hidup, trauma juga akan tetap hidup, walaupun tampak meredup bersembunyi di dalam ketidaksadaran. ${ }^{29}$ Renate Jost, "Debora in Der Neuen Welt, Trauma, Heilung Und Die Bibel," in Dem Tod Nicht Glauben, Sozialgeschichte Der Bibel, ed. Frank Crüsmann (Güterslah: Gütersloher
}

mengartikannya sebagai trauma psikis yang berhubungan dengan ketakutan yang intensif, ketidakberdayaan, kehilangan kontrol dan ancaman. ${ }^{30}$ Trauma menjangkiti mental dari korban, dan bukan fisiknya. Akan tetapi, trauma tersebut bisa disebabkan oleh luka fisik, atau tindak kekerasan langsung kepada fisik korban. Dengan demikian trauma melukai pikiran orang, mempengaruhi emosinya secara negatif, dan menyiksa secara berkelanjutan, karena itu proses penyembuhannya juga membutuhkan waktu yang lama. Trauma memiliki dampak yang bersifat kognitif, emosional, fisik, maupun perilaku terhadap orang yang mengalaminya.

Menurut Judith Herman, stress yang ditimbulkan oleh trauma biasanya tampak dalam tiga hal. ${ }^{31}$

1. Timbulnya rasa was-was tanpa alasan tentang kekerasan yang mungkin akan terjadi lagi.

2. Ingatan yang traumatis adalah sesuatu yang membeku di dalam ingatan korban, dan tampak selalu terjadi pada moment sekarang walaupun peristiwa tersebut sudah lama berlalu.

Verlagshaus, 2004), 271

${ }^{30}$ Judith Lewis Herman, Die Narben Der Gewalt.

Traumatische Erfahrungen Verstehen Und

Überwinden (Münschen: Kindler, 1994), 54

${ }^{31}$ Ibid., 56-65. 
3. Orang yang mengalami trauma seringkali juga merasa tidak berdaya, serta tidak mampu untuk menghadapi perasaan negatif itu.

Mengingat beratnya stress yang dialami, maka mereka yang mengalami trauma ingin agar semua ingatan akan pengalaman traumatis akibat kekerasan dan pelecehan seksual dihapus dari ingatan mereka (melupakan). Ingatan itu telah membuat mereka terluka dan tersiksa dalam hidup ini. Namun apakah memang orang bisa melupakan sesuatu yang sangat membekas dan menyakitkan dalam hidup? Orang lupa bahwa ketika orang berusaha untuk melupakan, pada saat yang sama ia sedang membangkitkan kembali ingatan pada pengalaman traumatis tersebut. ${ }^{32}$ Dan tindakan mengingat dan melupakan tidak perlu dipertentangkan karena justru menjadi cara memaknai masa lalu sambil membayangkan masa depan.

Sehubungan dengan hal itu, maka langkah yang paling penting bukan melupakan namun mengingat untuk menyembuhkan trauma ini. Ini yang disebut dengan penyembuhan melalui ingatan atau dengan cara mengingat kembali peristiwa tersebut. Dengan mengingat masa lalu yang menyakitkan

\footnotetext{
${ }^{32}$ Binsar Jonathan Pakpahan, "Ingatan Sebagai Dasar Rekonsiliasi Dalam Konflik," Diskursus 12,
}

atau menimbulkan pengalaman traumatis, lalu diselesaikan dan berdamai, maka pengalaman traumatis itu akan dilupakan untuk kemudian melanjutkan kehidupan selanjutnya dengan baik. ${ }^{33}$ Untuk itu, dibutuhkan upaya rekonsiliasi atau pendamaian, di mana korban mengampuni dan orang yang melakukan kejahatan menyesal atau bertobat (ada pertemuan di antara keduanya).

Shriver menunjukkan bahwa jalan terbaik untuk mengobati luka-luka fisik dan batin yang terjadi dalam sebuah komunitas politik adalah pengampunan dan rekonsiliasi, yang mempunyai empat elemen penting: (1) penilaian moral, (2) penolakan upaya balas dendam, (3) empati, (4) rekonsiliasi dan restorasi hubungan yang rusak. $^{34}$ Namun bagaimana hal ini akan terwujud bila kaum perempuan yang adalah korban terbanyak dalam konflik ini tidak dilibatkan dalam upaya rekonsiliasi tersebut? ${ }^{35}$ Kenyataan menunjukkan bahwa

no. 2 (Oktober 2013): 259.

${ }^{33}$ Binsar Jonathan Pakpahan, "Etika Mengingat Bagi Bangsa Pelupa," Ledalero 16, no. 1 (June 2017): 51.

${ }^{34}$ Seperti dikutip oleh Paulus Sugeng Widjaja,

"Rekonsiliasi Antar Umat Beragama: Refleksi Pengalaman Lapangan," in Perempuan, Konflik \& Rekonsiliasi, Perspektif Teologi Dan Praksis, ed. Asnath Niwa Natar and Basilica D. Putranti (Yogyakarta: PSTF UKDW, 2004), 74.

${ }^{35}$ Kendatipun perempuan tidak dilibatkan dalam upaya rekonsiliasi secara formal namun banyak di antara mereka yang sebenarnya memainkan peran penting dalam membangun perdamaian, misalnya melalui kegiatan di pasar, di mana pedagang dan pembeli Muslim dan Kristen bertemu. Upaya lain adalah apa yang dilakukan oleh Gerakan 
sangat sedikit keterlibatan kaum perempuan (dalam Perjanjian Malino untuk kasus Poso hanya ada 3 perempuan dari 48 penandatangan, sedangkan untuk kasus Maluku tidak ada perempuan yang terlibat) dalam usaha rekonsiliasi formal, ${ }^{36}$ padahal merekalah yang paling menderita, sementara mereka bukan penyebab konflik atau bukan konflik mereka. Akibatnya penderitaan dan permasalahan traumatik perempuan kurang mendapat perhatian. Suara para korban tidak didengarkan dan keterlukaan mereka seolah-olah bukan sesuatu yang serius. Padahal hanya jika masing-masing pihak yang terlibat dalam konflik bersedia mendengarkan jeritan dan ratapan para korban, maka rekonsiliasi yang tulus dan murni akan bisa diwujudkan. Kendati para pelaku kejahatan dihukum bahkan dihukum mati, namun tanpa memberikan perhatian kepada para korban maka proses rekonsiliasi dan pemulihan trauma tidak akan berjalan.

Salah satu contoh adalah kasus perkosaan yang dialami oleh seorang gadis di Jawa Timur. Ia diperkosa oleh kakek

Perempuan Peduli (GPP) yang merupakan gabungan dari perempuan Muslim, Kristen dan Katholik, atau upaya damai yang dilakukan oleh kelompok perempuan Kepulauan Kei di Maluku Tenggara. Lih. Lawalata, "Fakta Tak Terlihat, Posisi Perempuan Dalam Konflik Sosial Di Maluku," 14-19.

${ }^{36}$ Lih. Wijaksana, "Reruntuhan Jiwa: Trauma Perempuan Poso," 61; Subiyantoro, "Perempuan Di Wilayah Konflik Maluku, Menakar Hidup Di Ladang Bedil," 93. tirinya dan kakek tirinya ini sudah dihukum atas perbuatannya. Namun gadis ini tetap dalam trauma dan depresi berat. Ia tidak mau melakukan aktifitas apapun selain tidur dalam posisi tangan digenggam, tidak mau mandi dan keluar dari kamar sehingga ia harus buang air dan kotoran di kamarnya. Hal yang dilakukan oleh gereja hanya berdoa dan tidak ada upaya trauma healing.

Contoh lain adalah trauma yang dialami oleh perempuan Jugun Ianfu atau pelacur perang pada masa penjajahan Jepang di Indonesia. Untuk waktu yang sangat lama, negara Jepang tidak pernah meminta maaf kepada para korban atas kejadian ini, dan korbannya hidup dalam trauma yang berkepanjangan. Negara Jepang memang mengalami kekalahan dan sudah minta maaf kepada pemerintah Indonesia, namun tidak dengan para korban Jugun Ianfu. Demikian juga dengan trauma yang dialami oleh keluarga korban G30S/ PKI. Keluarga mereka ditangkap, dihukum dan dibunuh begitu saja tanpa proses pengadilan. Sampai dengan saat ini tidak ada permohonan maaf dari pemerintah terhadap keluarga korban yang terus hidup dalam trauma, penderitaan dan pengucilan dari masyarakat. Mereka menderita dan mendekap penderitaan itu sendiri dalam diam, tanpa teman.

Dari sini dapat dilihat bahwa 
pemberian hukuman pada pelaku adalah masalah legal (institusi) tetapi pengampunan, pemulihan trauma bagi korban adalah masalah personal. ${ }^{37}$ Karena itu pihak-pihak yang terlibat dalam konflik tidak bisa beranggapan bahwa waktu akan membuat luka-luka fisik dan batin yang terjadi sembuh dengan sendirinya. Waktu adalah musuh yang sangat berbahaya bagi ingatan sosial karena waktu mendorong seseorang untuk melarikan diri secara diam-diam dari kejahatan-kejahatannya. ${ }^{38}$ Lebih lanjut, trauma yang sama sekali tidak diatasi dapat berlangsung seumur hidup bahkan bisa diturunkan pada generasi berikutnya yang bisa jadi akan menimbulkan konflik baru atau melestarikan konflik yang ada. Sehubungan dengan hal ini dibutuhkan kesadaran dari setiap pihak untuk turut memikirkan proses pemulihan trauma para korban karena upaya ini memberikan kontribusi yang besar bagi proses rekonstruksi sosial secara keseluruhan.

Dalam rangka memulihkan kondisi para korban, khususnya perempuan yang mengalami trauma di daerah konflik, beberapa LSM di Maluku, seperti LSM assessment Yayasan Masnait dan LSM

\footnotetext{
${ }^{37}$ Proses peradilan, kendati memberikan sumbangan yang penting dalam proses pemulihan trauma, tetap saja bahwa ini lebih memberikan perhatian kepada pelaku dan bukan kepada korban. ${ }^{38}$ Pendapat Shriver yang dikutip oleh Widjaja, "Rekonsiliasi Antar Umat Beragama: Refleksi
}

Bakubae Maluku, telah melakukan pendampingan. Para korban diberdayakan agar menjadi pemrakarsa atas pemulihan diri mereka sendiri, sebab tanpa niat dari diri sendiri untuk sembuh maka kesembuhan itu sendiri tidak akan pernah terjadi. Dengan kata lain mereka sendiri yang terlibat aktif, sedangkan pihak luar hanya menyediakan dukungan, dorongan, afeksi dan perhatian. Caranya dengan melakukan penyadaran kepada para korban agar mereka menyadari dirinya sebagai orang-orang yang terluka (bukan menyangkali luka itu) dan bersedia mengungkapkan luka-luka itu secara tegas dan gamblang. ${ }^{39}$ Para korban diminta untuk membuang sampah emosi atau katarsis, menciptakan dukungan sosial dan membuat pemaknaan baru atas kejadian traumatis yang dialami. Metode yang digunakan bisa bervariasi, misalnya dengan metode story telling (penceritaan kembali).

Proses pemulihan trauma tersebut dimulai dengan melibatkan para korban di dalam proses komunikasi yang bersifat konstruktif, di mana setiap orang menceritakan pengalaman mereka, dan yang lain mendengarkan. Namun hal pertama yang dilakukan adalah berusaha

Pengalaman Lapangan," 76.

${ }^{39}$ Hontong Sefnat, "Menyoal Fakta Pusara Korban, Membangun Budaya Damai Di Halmahera," Diskursus 11, no. 2 (Oktober 2012): 219. 
membangkitkan rasa aman dan percaya dalam diri korban yang dimulai dengan cara mengontrol tubuh mereka sendiri (seperti kebutuhan untuk tidur, makan dan melakukan beberapa aktivitas) kemudian mengontrol lingkungan (seperti belajar mempercayai orang luar dan memaafkan). ${ }^{40}$ Perasaan aman akan mendorong korban untuk mengungkapkan dirinya, serta menceritakan secara detail pengalaman negatif yang pernah mereka alami.

Namun metode menceritakan kembali ini kadang sulit dilakukan karena adanya anggapan bahwa tindakan menceritakan sama dengan upaya mengorek luka lama dan ini akan sangat menyakitkan. Padahal upaya menceritakan kembali narasi pengalaman konflik dan trauma yang dialami bukan dimaksudkan untuk membuka luka lama atau meromantisasi pengalaman konflik tersebut, melainkan upaya mengungkap realitas sejarah dan dampak-dampaknya. ${ }^{41}$

Upaya ini memberikan tempat dan kesempatan bagi korban dan ceritanya untuk didengarkan, sekaligus memberikan pengakuan akan apa yang terjadi atas dirinya. Ada begitu banyak orang yang stress dan mengalami penderitaan dalam

${ }^{40}$ Wijaksana, "Reruntuhan Jiwa: Trauma Perempuan Poso," 60.

${ }^{41}$ Band. Margie Ivonne Ririhena-de Wanna, Merajut Identitas Eklesiologi Di Seputar Konflik hidupnya karena ketidakpedulian sesamanya dan tidak ada kesempatan untuk menyampaikan apa yang mereka pikirkan dan rasakan. Pengalaman kekerasan yang dialami sudah membuat mereka sangat menderita, namun ditambah lagi dengan pengabaian. Mereka dibungkam atau terbungkam, berdiam diri dan hidup dalam kesepian, sama seperti yang dialami oleh Tamar. Kendati ia sudah tiga kali berusaha untuk bersuara dan menyampaikan protesnya, namun suaranya tidak terdengar. Kisah Tamar dan kisah perempuan-perempuan korban di daerah konflik dianggap tidak penting untuk didengarkan. Akibatnya, mereka hanya bisa menyimpan sendiri rasa nyeri dan luka yang ada tanpa ada seorang pun yang mau menolongnya, bahkan untuk sekedar mendengarkan cerita mereka. Karena itu, menceritakan kembali pengalaman negatif memiliki fungsi terapis yang cukup tinggi, dan membuat korban mampu mengintegrasikan seluruh pengalaman negatif tersebut di dalam keseluruhan hidupnya untuk kemudian mampu bersosialisasi dengan orang lain lagi, dan menjalani kehidupan selanjutnya dengan lebih baik. Dalam konseling pastoral, proses penyembuhan dimulai, ketika seseorang mulai berbicara dan menceritakan kisahnya.

Lombok (Jakarta: BPK Gunung Mulia, 2015), 84 
Hal ini senada dengan apa yang dikatakan oleh Judith Lewis Herman tentang tiga ciri dari orang-orang yang telah menapaki secara positif proses pemulihan trauma, yakni perasaan nyaman, pengakuan diri, serta perasaan mulai terhubung kembali dengan dunia sosialnya. $^{42}$ Sharing bersama dalam kelompok yang memiliki pengalaman yang sama seperti korban perkosaan atau janda juga bisa menjadi cara yang efektif untuk mengurangi penderitaan dan trauma. Mereka yang sudah pulih bisa menjadi "yang terluka yang menyembuhkan" orang lain. Mereka memanfaatkan luka-luka mereka atau pengalaman terluka yang pernah dialami sebagai sumber kekuatan untuk membantu meringankan beban orang-orang lain yang senasib, bahkan untuk menyembuhkan. ${ }^{43}$ Dengan kata lain, mereka membalut luka-luka mereka sambil juga membalut luka-luka orang lain. Hal inilah yang dilakukan oleh Tuhan Yesus ketika Ia datang ke dalam dunia ini. Ia menderita dan terluka oleh perbuatan manusia, namun melalui pengalaman ini Tuhan Yesus justru ikut merasakan penderitaan manusia, terluka bersama dengan manusia, namun sekaligus menyembuhkan dan menyelamatkan

\footnotetext{
${ }^{42}$ Lihat Herman, Die Narben Der Gewalt. Traumatische Erfahrungen Verstehen Und Überwinden, 216.

${ }^{43}$ Lihat Ibid.
}

manusia. Ia adalah "Yang Terluka Yang Menyembuhkan".

Metode story telling bisa dilakukan dengan memanfaatkan momen-momen dan budaya lokal yang ada dalam masyarakat. Misalnya di Maluku, para perempuan suka sekali memakai bedak putih dan duduk di bawah pohon serta ngobrol. Saat ini bisa digunakan sebagai momen berbagi dan pemulihan, di mana setiap orang diberi kesempatan untuk mendengar cerita dari yang lain tanpa menyela. Ada bagusnya kalau acara ini dilakukan dalam kelompok yang terdiri dari para perempuan Kristen dan Islam. Mereka bisa saling bergantian menceritakan pengalamannya dari perspektif dia, dan yang lain mendengarkan dan menunjukkan empati.

Hal yang sama juga bisa dilakukan melalui kegiatan berjualan di pasar, di mana kelompok ibu-ibu dari Islam dan Kristen bertemu di pasar dan melakukan rekonsiliasi. Misalnya di Ambon, perempuan Islam dan perempuan Kristen berjualan di pasar yang sama dan mereka bisa berbagi kisah di antara mereka untuk mengetahui apa yang sesungguhnya terjadi pada komunitas lain: kehilangan sanak saudara, hancur dan hilangnya harta benda, depresi, terror, ketakutan. Di sini mereka bisa saling menguatkan tanpa memandang perbedaan agama.

Selain melalui penceritaan kembali 
secara lisan juga dapat dilakukan dengan cara bermain peran, menggambar dan menulis, atau dengan menggunakan metode yang cocok dengan kultur lokal, seperti budaya Pela Gandong ${ }^{44}$, kesenian daerah, menarik kekuatan dari leluhur, atau kelompok berbagi (sharing). ${ }^{45}$ Metode yang juga bisa dipakai untuk menyembuhkan para korban trauma adalah metode Imajinasi dan reaksi tubuh, ${ }^{46}$ di mana mereka membayangkan melalui latihan imajinasi dan latihan tubuh tertentu, sedang berada di dalam situasi yang menyenangkan. Misalnya dengan membayangkan tempat yang aman, malaikat pelindung, peri, binatang tertentu, melalui meditasi untuk menemukan sumber kekuatan di dalam diri atau melalui mimpi atau membayangkan sebuah dunia masa depan yang diimpikan (Utopia). Gambaran-gambaran ini akan mempengaruhi otot dan system saraf karena dalam meditasi tersebut, otot dan system saraf menjadi rileks, tubuh terasa nyaman dan mengalami ketenangan. Kondisi ini yang kemudian menghasilkan

\footnotetext{
${ }^{44}$ Pela Gandong adalah adanya persaudaraan antar kampung di mana umat beragama yang satu dengan lainnya memiliki tradisi saling menghormati. Lih. Tulisan Ina Soselisa, "Perempuan Cacat Konflik Di Ambon Dan Upaya Pemulihan," Jurnal Perempuan 33 (2004): 58.

${ }^{45}$ Band. Margaretha Ririmasse, Perempuan, Kekerasan \& Perdamaian. Sebuah Refleksi Teologis Feminis (Jakarta: Yakoma PGI, 2009), 119-124.

${ }^{46}$ Jost, "Debora in Der Neuen Welt, Trauma,
}

kesembuhan pada para korban. ${ }^{47}$

\section{KESIMPULAN}

Dalam upaya mengatasi dampak konflik terhadap kaum perempuan, perhatian dan penanganan tidak cukup hanya ditujukan pada masalah yang berkaitan dengan fisik, materi dan fasiltas yang hancur, namun juga memberi perhatian pada diri pribadinya. Belajar dari konflik-konflik yang pernah terjadi, seperti di Maluku dan di Poso, maka sangat perlu dilakukan pendampingan pastoral berupa traumahealing bagi perempuan korban kekerasan. Hal yang juga perlu diperhatikan adalah perlunya melibatkan kaum perempuan dalam upaya rekonsiliasi dan menghargai upaya-upaya rekonsiliasi yang mereka lakukan dengan cara mereka masing-masing. Kisah dan pergumulan kaum perempuan perlu didengarkan dan diberi tempat. Mereka tidak boleh dibungkam, namun sebaliknya harus diberi kesempatan untuk menceritakan dan mengungkapkan luka-luka yang mereka alami sebagai cara yang efektif untuk mengurangi trauma yang mereka rasakan untuk kemudian dapat melanjutkan hidup bersosialisasi dengan baik.

Heilung Und Die Bibel,” 279-280.

${ }^{47}$ Ibid., 281-284. Hal ini biasa dilakukan oleh para dukun yang pergi pada sebuah tempat di dunia batin dan menemukan pemimpin roh yang 


\section{DAFTAR PUSTAKA}

Ferranda, Ellen. "Sejarah Perang Ambon 1999 Secara Singkat Dan Lengkap." Sejarah Lengkap, December 17, 2018. Accessed September 4, 2019. https://sejarahlengkap.com/indones ia/sejarah-perang-ambon.

Gogali, Lian. Konflik Poso. Suara Perempuan Dan Anak Menuju Rekonsiliasi Ingatan. Yogyakarta: Galangpress, 2009.

Hackett, Jo Ann. "1 and 2 Samuel." In Women'n Bible Commentary, edited by Carol A. Newsom and Jaqueline E. Lapsley. Revised and Updated. Louisville, Kentucky: Westminster John Knox Press, 2016.

Herman, Judith Lewis. Die Narben Der Gewalt. Traumatische Erfahrungen Verstehen Und Überwinden. Münschen: Kindler, 1994.

Hubbard, M. Gay. Women: The Misunderstood Majority. USA: Word Publishing, 1992.

Humm, Maggie. The Dictionary of Feminist Theory. Second. New York, US: Prentice Hall, 1989.

Iwamony-Tiwery, Rachel. "Keterlibatan Dan Peran Perempuan Dalam Dialog Antar Umat Beragama Paska Konflik Di Ambon. Tinjauan Teologi Interkultural." In Ketika Perempuan Berteologi, edited by Asnath Niwa Natar. Yogyakarta: Taman Pustaka Kristen, 2012.

Jost, Renate. "Debora in Der Neuen Welt, Trauma, Heilung Und Die Bibel." In Dem Tod Nicht Glauben,

mendampinginya dengan saran dan perbuatan.
Sozialgeschichte Der Bibel, edited by Frank Crüsmann. Güterslah: Gütersloher Verlagshaus, 2004.

Kuswardono, Pantoro Tri, and Rosa M do $\mathrm{R}$ de Sousa, eds. Menyilam Kemarau. Upaya Perempuan Timor Loro Sae Menyudahi Kekerasan, Sebuah Awal. Dili: Forum Komunikasi Untuk Perempuan Loro Sae, 1999.

Lawalata, Julius. "Fakta Tak Terlihat, Posisi Perempuan Dalam Konflik Sosial Di Maluku." Jurnal Perempuan 33 (2004).

McGuire, M. Religion: The Social Context. California: Wadsworth Inc., n.d.

Muellner, Ilse. "Die Samuelbuecher. Frauan Im Zentrum Der Geschichte Israels." In Kompendium Feministishe Bibelauslegung, edited by Luise Schottroff and Marie-Theres Wacker. Guetersloh: Guetersloher Verlaghaus, 2007.

Pakpahan, Binsar Jonathan. "Etika Mengingat Bagi Bangsa Pelupa." Ledalero 16, no. 1 (June 2017).

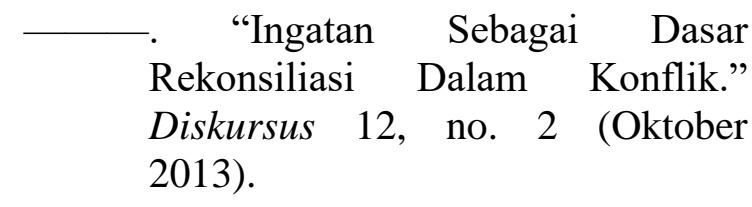

Rahabeat, Rodolf. "Potret Perempuan (Berteologi) Di Ruang Konflik." In Perempuan, Konflik Dan Rekonsiliasi, Perspektif Teologi Dan Praksis, edited by Asnath Niwa Natar and Basilica D. Putranti. Yogyakarta: PSTF UKDW, 2004.

Ririhena-de Wanna, Margie Ivonne. Merajut Identitas Eklesiologi Di Seputar Konflik Lombok. Jakarta: BPK Gunung Mulia, 2015. 
Ririmasse, Margaretha. Perempuan, Kekerasan \& Perdamaian. Sebuah Refleksi Teologis Feminis. Jakarta: Yakoma PGI, 2009.

Sefnat, Hontong. "Menyoal Fakta Pusara Korban, Membangun Budaya Damai Di Halmahera." Diskursus 11, no. 2 (Oktober 2012).

Soselisa, Ina. "Perempuan Cacat Konflik Di Ambon Dan Upaya Pemulihan." Jurnal Perempuan 33 (2004).

Subiyantoro, Eko Bambang. "Perempuan Di Wilayah Konflik Maluku, Menakar Hidup Di Ladang Bedil." Jurnal Perempuan 24 (2002).

Subono, Nur Iman. "Konflik Bersenjata, Kekerasan Militer Dan Perempuan." Jurnal Perempuan 24 (2002).

Tiwery, Weldemina Yudit. Teologi Ina.
Terlahir Dari Rahim Maluku. Jakarta: BPK Gunung Mulia, 2015.

Widjaja, Paulus Sugeng. "Rekonsiliasi Antar Umat Beragama: Refleksi Pengalaman Lapangan." In Perempuan, Konflik \& Rekonsiliasi, Perspektif Teologi Dan Praksis, edited by Asnath Niwa Natar and Basilica D. Putranti. Yogyakarta: PSTF UKDW, 2004.

Wijaksana, M. B. "Reruntuhan Jiwa: Trauma Perempuan Poso." Jurnal Perempuan 24 (2002).

"Kerusuhan Poso." Wikipedia bahasa Indonesia, ensiklopedia bebas, August 3, 2019. Accessed September 2019. https://id.wikipedia.org/w/index.ph $\mathrm{p}$ ?title $=$ Kerusuhan_Poso\&oldid $=15$ 423747. 